\title{
CORRUPTION IN SOUTH AFRICA: GENESIS AND OUTLOOK
}

\author{
Natasha Georgieva Hadji Krsteski \\ University MIT, Faculty of Security, Skopje, Macedonia \\ natashageorgievaivanovska@gmail.com
}

\begin{abstract}
Corruption in South Africa includes the private use of public resources, bribery and improper favouritism. South Africa scored 45 points out of 100 on the 2016 Corruption Perceptions Index reported by Transparency International. Corruption Index in South Africa averaged 46.97 Points from 1996 until 2016, reaching an all-time high of 56.80 Points in 1996 and a record low of 41 Points in 2011. A tenderpreneur is common corruption in South Africa. It is an individual who enriches themselves through corrupting the awarding of government tender contracts, mostly based on personal connections and corrupt relationships - although outright bribery might also take place - and sometimes involving an elected or politically appointed official (or his or her family members) holding simultaneous business interests. This is often accompanied by overcharging and shoddy workmanship. BEE-fronting is an abuse of the rules governing Black Economic Empowerment (BEE), where qualifying persons are given a seat on the Board of Directors of a company while having no decision-making power in the company, in order to qualify the company for government contracts in terms of BEE.
\end{abstract}

Key words: Corruption, fraud, bribery, South Africa, BEE

\section{Introduction}

Government initiatives against corruption are coordinated by the Department of Public Service and Administration. The Public Protector also plays a role in fighting corruption. A disbanded independent unit Scorpions (South Africa) was replaced by the Hawks (South Africa) which is subordinate to the police's "The Directorate for Priority Crime Investigation ".

Notable incidents of fraud and corruption:

- The South African Arms Deal, finalized in 1999, became mostly known for the bribery that was used to gain the contracts. The Schabir Shaik trial arose partly from this scandal.

- The Travelgate scandal, in which forty Members of Parliament were found to have illegally used parliamentary travel vouchers worth R18,000,000 for personal use.

- The Goodwood police station commander, Siphiwu Hewana, was found guilty of attempting to defeat the ends of justice by tampering with the docket for convicted fraudster Tony Yengeni's arrest for driving under the influence in 2007.

- Former National Police Commissioner and ex-President of Interpol, Jackie Selebi, was convicted on corruption charges in July 2010, for receiving (at least) R120,000 from alleged crimesyndicate boss, Glenn Agliotti.

\section{Level of corruption in South Africa}

A new index looking at corruption and justice aims gives insight into how people experience rule of law in everyday life - in South Africa and around the world. The WJP Rule of Law Index 2017 is based on data from 100,000 household and expert surveys in 102 countries and jurisdictions. 
Of the 102 countries measured, South Africa ranks 36th, on par with countries including Hungary and Croatia, but far below global leaders, Denmark, Norway and Sweden. South Africa ranks third in Africa, below Botswana and Ghana, which rank 31st and 34, respectively. (Brogden, M. and P. Nijhar, 2008, p. 175)

Constraints on government powers $-40^{\text {th }}-$ South Africa scored highly for its independent government watch-dogs, but scored low for its capacity to impose sanctions for official government misconduct.

Absence of Corruption - $42^{\text {nd }}$ - outh Africa's average performance in this indicator was highlighted by being better at keeping corruption out of the judiciary than keeping corruption out of the legislature - one of the weakest ratings overall.

Open government $-27^{\text {th }}-$ Overall South Africa rated well for its civic participation in government, but came up lacking in the way government publicized laws and other government data.

Fundamental Rights $-39^{\text {th }}$ - South Africa performed fairly strongly in this indicator, above average across all points except for the due process of the law in the country. Freedom of expression, religion and association were the strongest factors.

Order and Security $-81^{\text {st }}$ - While South Africa scored top marks for the absence of civil conflict, high crime rates and violence knocked it down to 81 st out of 102 countries.

Regulatory Enforcement - $33^{\text {rd }}$ - South Africa had an above average performance across all factors in this indicator, but dropped the ball by having unreasonable delays in regulatory processes.

Civil Justice $-39^{\text {th }}$ - South Africa scored well for having a civil justice system with low levels of corruption and government influence - but was dragged down for high costs and discrimination, which were both below average.
Criminal Justice $-38^{\text {th }}$ - South Africa's average performance in this indicator was marred by an ineffective correctional system, and taking too long to be processed in the system. (Business Anti-Corruption Portal, 2017, pp 88-93)

\section{The etiology of corruption in South Africa}

Complacency underpins a dismal track record for effectively dealing with foreign corruption and bribery in South Africa. Looking at cases of bribery and money laundering in the country, can be found a serious lack of enforcement actions in South Africa, noting a seemingly passive approach to, and lack of significant investigative efforts in existing cases. The South African authorities have not been sufficiently proactive - neither in generating new investigations nor in investigating existing ones. Worryingly, the number of foreign bribery allegations appears low, given South Africa's economic links to a number of countries with corruption risks. South Africa has not led any prosecutions in ten known foreign bribery cases since becoming party to the anti-corruption convention in 2007.

\section{The place of corruption in South Africa}

As many as $38 \%$ of 2,200 incidents reported to Corruption Watch in 2013 originated in Gauteng. This is followed by the Free State with 14\%, and Kwa-Zulu Natal and the Eastern Cape with $13 \%$ each. Most corrupt activities take the form of bribery, nepotism and abuse of public funds. Only 58\% of all reported corruption had confirmed corrupt activities taking place. Of all reports in 2017, a large portion (38\%) related to schools, followed by traffic and licensing (10\%), healthcare (3\%) and water (2\%). Most reports - $43 \%$ - involved the abuse of government resources by a public official. (Bloom, J., 2010, p. 77) 


\section{Battle with corruption}

South Africa is fighting a losing battle against corruption, with graft costing taxpayers nearly one billion rand (\$111 million) last year. Although 88 percent of people tried for financial misconduct are found guilty only 19 percent are dismissed. Most get off with a written warning and remain in government service and continue stealing. The corruption "is rampant, it is out of control" and units fighting it "are essentially losing the battle." (Carmerer, L., 2000, p. 61)

\section{Major reasons for corruption in South Africa}

South Africans certainly think that public sector corruption is getting worse. Transparency International's (TI) 2017 global Corruption Perception Index (CPI) shows that South Africa has dropped 34 places since 2001, with half the decline of 17 places occurring since 2009. South Africa is currently ranked at number 72 out of 175 countries and heading downwards. The Human Sciences Research Council's (HSRC) annual South African Social Attitudes Survey shows the proportion of people who think that tackling corruption should be a national priority almost doubling, from $14 \%$ to $26 \%$ in the five-year period between 2006 and 2011. This trend is supported by the latest 2017 Afrobarometer report, Governments falter in fight to curb corruption, released on 13 September 2017. (Lodge, T, 2008, p. 74) The report, based on surveys of 51000 people in 34 African countries, shows that South Africa is one of the countries where there is a notable increase in public perceptions that corruption is getting worse, particularly since 2008. This is in contrast with countries such as Botswana, Malawi, Mozambique, Senegal and Zambia, where people believe that their governments are making gains in curbing public sector corruption. Interestingly, South Africa is better placed than many other African countries to tackle this problem. There are 13 public sector agencies that have a particular legal or policy role to play in combatting graft. Moreover, a number of national mechanisms - such as the National Anti-Corruption Task Team - have been established to coordinate the functions of these agencies. South Africa also has dedicated policies, standards and legislation specifically designed to enable the state to tackle corruption through both criminal and civil action. The question then becomes, why, with all these resources available to tackle corruption, South Africans perceive the government to be failing in this regard. For example, Afrobarometer has found that on average a little over half $(56 \%)$ of people on the African continent thought that their governments were doing a poor job in "their efforts to fight corruption". However, South Africa performed notably worse than the average, with two out of three citizens (66\%) believing the government to be performing poorly in combatting graft. Importantly, these opinions are not held because South Africans are regularly confronted with public sector corruption. In fact, the 2013 Afrobarometer report shows that South Africa was ranked fifth lowest among African countries when it came to citizens having direct experiences of paying a bribe for public services. Only $15 \%$ of South Africans said that they had paid a bribe in the previous year compared with an average of $30 \%$ of Africans who had paid a bribe. The worst performer was Sierra Leone, where $63 \%$ said that they had paid a bribe. So why do South Africans have such negative perceptions of corruption? Arguably, it is because although most people are not expected to pay a bribe to access a public service, the public are aware that politicians and public officials divert public funds away from service delivery into their back pockets. In 2011 the former head of the Special Investigation Unit, Willie Hofmeyer, reported before parliament that between R25 billion and R30 billion was lost to the government procurement budget each year due to this type of fraud. 
Moreover, there is evidence that incidents of corruption are increasing. A report by Edward Nathan Sonnenbergs, based on documented fraud and malfeasance cases presented to parliament and contained in Public Service Commission reports, found that the amount involved increased from R130-million in $2006 / 07$ to over R1-billion in 2011/12. So there is evidence that the heart of the problem lies in the lack of accountability for maladministration and corruption. Corruption Watch states that this problem starts with the president - while there are various efforts by the government to tackle corruption, "these actions were countered by the continuing impunity on the part of those who were politically and financially powerful". In particular, it was explained that the "Gupta wedding saga and on-going fiasco surrounding the president's private Nkandla residence are indicators in the past year of impunity in operation". Little symbolises the nature of our public sector corruption challenge better than the scandal of R215million of public money being diverted away from the public good to upgrade President Jacob Zuma's private homestead. (Meldrum, A., 2005, p. 45) It is therefore not surprising that research data supports the argument that corruption committed by politicians and government officials is driving negative public perceptions of corruption in South Africa. According to the 2017 Afrobarometer Survey, perceptions of the office of the president being corrupt more than doubled, from a low of $13 \%$ in 2002 to $35 \%$ in 2011. This finding is backed up by the latest Future Fact Survey released last week that showed "a massive slide in trust and confidence in President Zuma to a current score of 37 from a high of 257 five years ago". President Zuma is not solely responsible for all corruption in the public sector, but he certainly has stymied any progress that could have been made in this regard. In addition to his own shady dealings with people like convicted fraudster Shabir Shaik, he has repeatedly appointed people of low ethical standards to key positions in cabinet and the criminal justice system. As a result, citizens are less trusting of their national leaders. This is reflected in the recently released 2017 South African Reconciliation Barometer survey undertaken by the Institute for Justice and Reconciliation. This survey revealed that since 2012 there has been a $10.8 \%$ decrease in citizens' confidence in national government. There has also been a $13 \%$ increase in the proportion of citizens who feel that government does not care about "people like them". This can partly be explained by the sad reality that some in the ruling elite have jettisoned principle for political power (see The danger of sacrificing principle at the altar of greater power). In order to truly honour Mandela, it is now up to those men and women of principle in the ANC and the broader alliance to step forward and start taking to task those who besmirch his proud legacy. There is no moral justification for the spending on Nkandla and the unethical behaviour of some of our cabinet ministers. Rather than trying to justify the indefensible or attacking important institutions such as the public protector, the ANC now needs to be at the forefront of holding its leaders to account for corruption and maladministration. Failing to do so will not only undermine Mandela's proud legacy, but will also further damage South Africa's prospects of solving its most pressing problems of poverty, unemployment and inequality.

\section{High corruption risk in the South African defence environment}

South Africa faces a high risk of corruption when it comes to defence, with the greatest risk of corruption among South African troop deployments. South Africa, a significant troop contributor to UN missions with 6000 personnel deployed on internal and external missions, was at particular risk of corruption on operations. But there are concerns across all risk areas. 
Political considerations were found to play a strong role in appointments and promotions, and have resulted in an absurdly high ratio of general's per soldier, undermining the professionalism of the military and destroying morale. In spite of an extensive anti-corruption framework in South Africa, there is low public trust. The framework includes anti-corruption legislation, a defence corruption and fraud prevention plan, and the Directorate for Priority Crime Investigation (also known as the Hawks).The effectiveness of those systems is questionable and public trust in defence institutions is low. Allegedly, corrupt activities are not addressed appropriately, including in well-known scandals. The Hawks are seen to be affected by executive influence. Regarding political power structures and favouritism, Political considerations play a strong role in the promotions of personnel and alignment to the ANC appears to increase one's chances of selection and promotion, even when there is no position to be filled. This may be one reason why South Africa has one of the highest general troop ratios world-wide, which is expensive and ineffective. It also has a significant impact on the morale of soldiers. Defence procurement transparency and accountability is severely limited by secret budgets, such as the Special Defence Account. Evidence indicates that this account is being used for a significant amount of non-secret procurement in order to avoid legislative provisions, reporting, and oversight. This is especially problematic as defence procurement has been marred by allegations of opportunistic purchases. As offset programmes are a substantial part of the South African defence trade worldwide, the use of arms trade offsets to bribe public officials has been a major allegation in defence procurement in recent years. There is very little detail given on past or current offset programmes. Furthermore, there is no evidence that offset contracts are subject to competition regulations or due diligence requirements. The Auditor General (AG) found irregularities in expenditure to the tune of R1 billion.
However, there were no repercussions for the misappropriation of funds nor did the Defence Minister meet once with the Auditor General to discuss the findings and how they would be followed up. The Protection of State Information Bill (Secrecy Bill), which is waiting for Presidential sign-off, will, only make access to information harder, while significantly reducing protection for whistleblowers. (Newman, G., 2002, p. 63) Over half of G20 countries lack adequate checks and balances over their military forces, posing a threat to international stability. 8 of the G20 states assessed in the index receive either D or E grade, representing either a "high" or "very high" risk of defence corruption. South Africa was placed in the bottom third of the G20, in band D. The actions of the G20 have a disproportionate impact on global security. Together they are responsible for the vast majority of global defence spending, the generation and trade of much of the world's most devastating weaponry, while their role in international interventions has a direct impact on the lives of millions of people across the globe. The G20 accounts for $82 \%$ of global defence spending, but much of this spending remains highly secretive. Only in seven countries is there any meaningful oversight over the defence budget at all. But while G20 defence spending has been increasing rapidly by $55.7 \%$ per cent in the ten years between 2007 and 2017 - there is little common understanding about how this power should be governed. And global military expenditure is rising fastest in exactly those places where governance appears weakest - the BRICs top the table for growth: Chinese military spending has increased by $441 \%$ in the last decade, Brazil by $225 \%$, Russia by $303 \%$ and India by $147 \%$. Only the UK scored top marks overall, thanks to strong, independent oversight mechanisms. 
France was ranked lowest in the G7, with risks to operations assessed as particularly high, despite the country deploying over 10,000 troops on international peacekeeping and stabilisation missions. (Newman, G. \& Faull, A., 2011, p. 170).

The US was awarded a B. Although systems were assessed to be relatively strong, the report judged that the US Department of Defence's failure to complete a full audit of its financial records and weaknesses in Congressional oversight created corruption risks.

\section{Conclusion}

South Africa's lack of action on corruption is not immediately clear, but investigators were concerned that "political and economic considerations" may be influencing the investigation and prosecution of foreign bribery. The offences do not raise any issues with South Africa's "robust regulatory framework", but argued that there was no case law on foreign bribery in the country, so the point is almost moot. In almost 10 years since the entry into force of South Africa's foreign bribery legislation in 2004, no natural or legal persons have been convicted for foreign bribery. No references or stats on the issue could be found in data from National Prosecuting Authority (NPA) or the Specialised Commercial Crimes Unit (SCCU).
R25-30 billion - or 20\% of the South African government's annual procurement budget was lost to corruption. Against this backdrop, it appears that South Africa's regime of corporate liability for intentional economic offences - while broad and flexible in theory and in force since at least 1977 - is given little priority and remains hardly enforced in practice.

\section{References}

[1] Brogden, M. and P. Nijhar (2008). Corruption and the South Africa Police: Crime, Law and Social, Cape Town

[2] Business Anti-Corruption Portal (2017). "Business Corruption in South Africa". Johannesburg

[3] Bloom, J. (2010). "Empowerment vs Tenderpreneurship". Politicsweb. Pretoria

[4] Carmerer, L. (2000). Just how corrupt is South Africa?, Business day, Garland Publishing. New York

[5] Meldrum, A. (2005). "40 accused in South African MPs' fraud case". The Guardian. Pretoria.

[6] Newman, G. (2002). Tackling Police corruption in South Africa: South Africa: Centre for the study of violence and reconciliation. Cape Town

[7] Newman, G. \& Faull, A. (2011). Protector or Predator: Tackling Police Corruption in South Africa. ISS Monograph 182, South Africa, Institute for Security Studies. 